\title{
Xylarinic Acids A and B, New Antifungal Polypropionates from the Fruiting Body of Xylaria polymorpha
}

\author{
Yun-Woo Jang, In-Kyoung Lee, Young-Sook Kim, Sangku Lee, Ho-Jae Lee, \\ Seung Hun Yu, Bong-Sik Yun
}

Received: September 5, 2007 / Accepted: October 22, 2007

(C) Japan Antibiotics Research Association

\begin{abstract}
Two new polypropionates designated as xylarinic acids A and B were isolated from the fruiting body of Xylaria polymorpha. Their structures were established as 4,6,8-trimethyl-2,4-decadienoic acid and 2,4,6-trimethyl-2-octenoic acid, respectively, on the basis of extensive spectroscopic analysis. Both compounds displayed significant antifungal activity against plant pathogenic fungi Pythium ultinum, Magnaporthe grisea, Aspergillus niger, Alternaria panax, and Fusarium oxysporium, whereas they did not show antibacterial and cytotoxic effect.
\end{abstract}

Keywords Xylaria polymorpha, mushroom, xylarinic acid, polypropionate, antifungal activity

\section{Introduction}

Mushrooms produce a large variety of secondary metabolites with unique chemical structures and interesting biological activities. In the course of screening for antimicrobial agents from our mushroom extract library (about 300 species of mushrooms), we found that the extract of the fruiting body of Xylaria polymorpha exhibited potent antifungal activity against the plant pathogenic fungi. Xylaria, belonging to the Ascomycotina, is known to produce diverse classes of bioactive compounds including

B.-S. Yun (Corresponding author), Y.-W. Jang, I.-K. Lee, Y.-S. Kim, S. Lee, H.-J. Lee: Korea Research Institute of Bioscience and Biotechnology (KRIBB), 111 Gwahangno, Yuseong-gu, Daejeon 305-806, Korea, E-mail: ybs@kribb.re.kr

S. H. Yu: Department of Applied Biology, Chungnam National University, Daejeon 305-764, Korea cytochalasin analogs [1], antifungal metabolites multiplolides $A$ and B [2], NPY Y5 receptor antagonists xyarenals A and B [3], acetylcholine esterase inhibitors xyloketals A E [4], xylariamide A [5], and xanthones [6].

In this study, two new polypropionates, xylarinic acids A (1) and B (2) (Fig. 1), have been isolated from the extract of the mushroom $X$. polymorpha by using antifungal activity-guided fractionation. We herein describe the isolation, structure determination, and antifungal activity of these compounds.

\section{Materials and Methods}

\section{General Experimental Procedures}

Optical rotation was determined using a JASCO P-1020 polarimeter. EI-MS and high resolution EI-MS were taken on a JMS-700 JEOL mass spectrometer. UV and IR spectra were recorded on a Shimadzu UV-300 and FT-IR Equinox 55 spectrometer, respectively. NMR spectra were obtained<smiles>CCC(C)CC(C)C=C(C)C=CC(=O)O</smiles><smiles>CCC(C)CC(C)C=C(C)C(=O)O</smiles>

Fig. 1 Structures of xylarinic acids A (1) and B (2). 


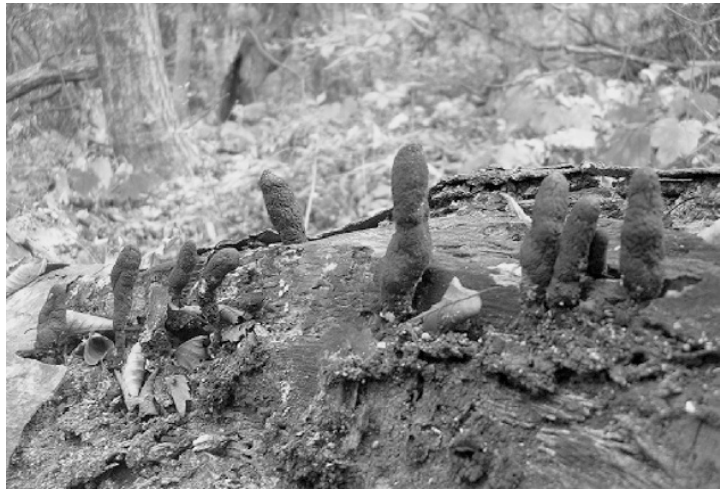

Fig. 2 Photograph of the fruiting bodies of Xylaria polymorpha.

on a Varian UNITY Inova NMR spectrometer with ${ }^{1} \mathrm{H}$ $\mathrm{NMR}$ at $400 \mathrm{MHz}$ and ${ }^{13} \mathrm{C}-\mathrm{NMR}$ at $100 \mathrm{MHz}$ in $\mathrm{CDCl}_{3}$. Chemical shifts are given in ppm $(\delta)$ using TMS as internal standard.

\section{Mushroom Material}

The dried mushroom $X$. polymorpha $(285 \mathrm{~g})$ was collected in the Gwangneung forest in Gyeonggi province, Korea, in October 2006, and identified by the staff at the Korea Research Institute of Bioscience and Biotechnology (KRIBB), according to the taxonomic key of Imazeki and Hongo [7].

\section{Antimicrobial Activity}

Antimicrobial activity was determined by the conventional paper disk (Advantec, $8 \mathrm{~mm}$ in diameter) method. The test microorganisms including 12 phytopathogenic fungi (Pythium ultinum, Fusarium oxysporium, Magnaporthe grisea, Aspergillus niger, Alternaria panax, Phytophthora capsici, Alternaria mali, Alternaria porri, Botrytis cinerea, Rhizoctonia solani, Fulvia fulva, Cylindrocarpon destructans) and three bacteria (Salmonella sendai, Staphylococcus aureus, Bacillus subtilis) were supplied from the Korean Collection for Type Cultures (KCTC) in the KRIBB, Korea. The paper disks containing each of $50 \mu \mathrm{g}$ sample were placed on agar plate inoculated with the test organisms. Antibiotic activity was assessed by measuring the diameter of inhibition zone after incubation of 24 hours at $37^{\circ} \mathrm{C}$ for bacteria, whereas after incubation of $2 \sim 7$ days at $27^{\circ} \mathrm{C}$ for fungi.

\section{Cytotoxicity}

The cytotoxicity was determined by measuring the reduction product of 3-[4,5-dimethylthiazol-2-yl]-2,5diphenyltetrazolium bromide (MTT) [8]. In brief, cells were pre-cultured in 96-well plates with $180 \mu 1$ of DMEM containing 5.0\% FBS for 24 hours. This was then added to diluted sample solution to a final volume of $200 \mu \mathrm{l}$ and cultured under $5.0 \% \mathrm{CO}_{2}$ at $37^{\circ} \mathrm{C}$ for 48 hours. MTT was dissolved in phosphate-buffered saline and added to the cell culture. After 2 hours, the medium was removed and the remaining MTT crystals were dissolved in $100 \mu \mathrm{l}$ of DMSO. The absorbance was measured at $570 \mathrm{~nm}$ with a background correction at $690 \mathrm{~nm}$.

\section{Results}

\section{Isolation and Purification of Xylarinic Acids A and B}

The ground fruiting bodies of $X$. polymorpha were extracted twice with $\mathrm{MeOH}$ at room temperature for 2 days. After removal of $\mathrm{MeOH}$ under reduced pressure, the concentrate was partitioned between hexane and $\mathrm{H}_{2} \mathrm{O}$ and then $\mathrm{CHCl}_{3}$ and $\mathrm{H}_{2} \mathrm{O}$. The concentrated hexane-soluble portion was subjected to a column of silica gel and eluted with increasing amount $(2.0 \%, 5.0 \%, 10 \%, 20 \%$, and $50 \%$, stepwise) of EtOAc in hexane to give two antifungal fractions. One was chromatographed on a column of Sephadex LH-20 with $\mathrm{CHCl}_{3}: \mathrm{MeOH}(1: 1, \mathrm{v} / \mathrm{v})$ to give $\mathbf{1}$ (200 mg). The other was purified by ODS column chromatography with $70 \%$ aqueous $\mathrm{MeOH}$ to afford 2 $(1.5 \mathrm{mg})$.

\section{Physico-chemical Properties}

1 was obtained as a colorless oil and was soluble in $\mathrm{CHCl}_{3}$, DMSO, and $\mathrm{MeOH}$ and insoluble in $\mathrm{H}_{2} \mathrm{O}$. Its molecular formula was determined to be $\mathrm{C}_{13} \mathrm{H}_{22} \mathrm{O}_{2}$ by high-resolution EI-MS measurement (found 210.1620, calcd 210.1620). The UV spectrum of $\mathbf{1}$ showed absorption maxima at $262 \mathrm{~nm}$, which can be ascribed to an $\alpha, \beta, \gamma, \delta$-unsaturated carbonyl group, and $202 \mathrm{~nm}$. The IR spectrum of 1 exhibited absorption bands due to hydroxyl $\left(3440 \mathrm{~cm}^{-1}\right)$ and $\alpha, \beta$-unsaturated carbonyl $\left(1690 \mathrm{~cm}^{-1}\right)$ groups. 1 has an optical rotation value of $\alpha_{\mathrm{D}}^{25}-69.6(c 10, \mathrm{MeOH}) .2$ was also obtained as a colorless oil of small amount, and its molecular formula, $\mathrm{C}_{11} \mathrm{H}_{20} \mathrm{O}_{2}$, was determined by highresolution EI-MS measurement (found 184.1459, calcd 184.1463). The UV spectrum of 2 exhibited an absorption maximum at $214 \mathrm{~nm}$, which can be ascribed to an $\alpha, \beta$ unsaturated carbonyl group. $\mathbf{2}$ has an optical rotation value of $\alpha_{\mathrm{D}}^{25}-25.0(c 0.1, \mathrm{MeOH})$.

\section{Structure Determination}

Chemical structures of $\mathbf{1}$ and $\mathbf{2}$ were determined by NMR spectroscopic analysis. The ${ }^{1} \mathrm{H}-\mathrm{NMR}$ spectrum showed the signals due to three olefinic methine protons at $\delta 7.38$, 
Table $1{ }^{1} \mathrm{H}$ - and ${ }^{13} \mathrm{C}$-NMR spectral data of compounds xylarinic acids $\mathrm{A}(\mathbf{1})$ and $\mathrm{B}(\mathbf{2})$ in $\mathrm{CDCl}_{3}{ }^{a}$

\begin{tabular}{|c|c|c|c|c|}
\hline \multirow{2}{*}{ No. } & \multicolumn{2}{|r|}{1} & \multicolumn{2}{|r|}{2} \\
\hline & $\delta_{\mathrm{C}}$ & $\delta_{\mathrm{H}}$ & $\delta_{\mathrm{C}}$ & $\delta_{\mathrm{H}}$ \\
\hline 1 & 173.6 & & 172.7 & \\
\hline 2 & 114.9 & $5.76(1 \mathrm{H}, \mathrm{d}, J=15.6)^{b}$ & 125.4 & \\
\hline 3 & 152.6 & $7.38(1 \mathrm{H}, \mathrm{d}, J=15.6)$ & 151.3 & $6.66(1 \mathrm{H}, \mathrm{dd}, J=10.0,1.2)$ \\
\hline 4 & 131.4 & & 31.3 & $2.64(1 \mathrm{H}, \mathrm{m})$ \\
\hline \multirow[t]{2}{*}{5} & 150.4 & $5.67(1 \mathrm{H}, \mathrm{d}, J=10.0)$ & 44.2 & $1.38(1 \mathrm{H}, \mathrm{m})$ \\
\hline & & & & $1.16(1 \mathrm{H}, \mathrm{m})$ \\
\hline 6 & 31.2 & $2.64(1 \mathrm{H}, \mathrm{m})$ & 32.5 & $1.27(1 \mathrm{H}, \mathrm{m})$ \\
\hline \multirow[t]{2}{*}{7} & 44.6 & $1.30(1 \mathrm{H}, \mathrm{m})$ & 30.2 & $1.30(1 \mathrm{H}, \mathrm{m})$ \\
\hline & & $1.09(1 \mathrm{H}, \mathrm{m})$ & & $1.16(1 \mathrm{H}, \mathrm{m})$ \\
\hline 8 & 32.6 & $1.23(1 \mathrm{H}, \mathrm{m})$ & 11.4 & $0.86(3 \mathrm{H}, \mathrm{t}, J=7.2)$ \\
\hline \multirow[t]{2}{*}{9} & 29.9 & $1.30(1 \mathrm{H}, \mathrm{m})$ & 12.3 & $1.87(3 \mathrm{H}, \mathrm{d}, J=1.2)$ \\
\hline & & $1.13(1 \mathrm{H}, \mathrm{m})$ & & \\
\hline 10 & 11.5 & $0.82(3 \mathrm{H}, \mathrm{t}, J=7.2)$ & 20.6 & $1.01(3 \mathrm{H}, \mathrm{d}, J=6.4)$ \\
\hline 11 & 12.5 & $1.79(3 \mathrm{H}, \mathrm{s})$ & 19.2 & $0.84(3 \mathrm{H}, \mathrm{d}, J=6.0)$ \\
\hline 12 & 21.2 & $0.97(3 \mathrm{H}, \mathrm{d}, J=6.4)$ & & \\
\hline 13 & 19.2 & $0.80(3 \mathrm{H}, \mathrm{d}, J=6.4)$ & & \\
\hline $\mathrm{OH}$ & & $11.82(1 \mathrm{H}, \mathrm{br} \mathrm{s})$ & & \\
\hline
\end{tabular}

${ }^{a} \mathrm{NMR}$ data were measured at $400 \mathrm{MHz}$ for proton and at $100 \mathrm{MHz}$ for carbon.

${ }^{b}$ Proton resonance integral, multiplicity, and coupling constant $(J=\mathrm{Hz})$ are in parentheses.

5.76, and 5.67, two methylenes, two methines, and four methyl protons at $\delta 1.79,0.97,0.82$, and 0.80 (Table 1 ). In the ${ }^{13} \mathrm{C}$-NMR spectrum, a carbonyl carbon, three $s p^{2}$ methine carbons, one $s p^{2}$ quaternary carbon, two $s p^{3}$ methine carbons, two $s p^{3}$ methylene carbons, and four methyl carbons were evident. The ${ }^{1} \mathrm{H}-{ }^{1} \mathrm{H}$ COSY experiment established a diene moiety and a partial structure of C-5 to $\mathrm{C}-10$, suggesting that $\mathbf{1}$ has a polypropionate moiety (Fig. 3). The structure of $\mathbf{1}$ was determined by the HMBC experiment, which showed the long-range correlations from $\mathrm{H}-2$ to $\mathrm{C}-1$ and $\mathrm{C}-4$, from $\mathrm{H}-3$ to $\mathrm{C}-1$ and $\mathrm{C}-5$, from $\mathrm{H}-5$ to C-3, C-7, C-11, and C-12, from H-6 to C-4 and C-8, from $\mathrm{H}-7$ to $\mathrm{C}-9, \mathrm{C}-12$, and $\mathrm{C}-13$, from $\mathrm{H}-10$ to $\mathrm{C}-8$ and $\mathrm{C}-9$, from $\mathrm{H}-11$ to $\mathrm{C}-3, \mathrm{C}-4$, and $\mathrm{C}-5$, from $\mathrm{H}-12$ to $\mathrm{C}-5$, C-6, and $\mathrm{C}-7$, from $\mathrm{H}-13$ to $\mathrm{C}-7, \mathrm{C}-8$, and $\mathrm{C}-9$, as shown in Fig. 3. The $E$ configuration of the double bonds of $\mathrm{C}-2$ and C-4 was assigned on the basis of the proton coupling constants of $15.6 \mathrm{~Hz}$ and carbon chemical shift of C-11 having $\gamma$-effect, respectively. We planned to determine the stereochemistry of $\mathbf{1}$ at C-6 and C-8 by oxidative degradation with $\mathrm{NaIO}_{4}$ and $\mathrm{KMnO}_{4}$ and comparison of the optical rotation value of the reaction product, 2,4-dimethylhexanoic acid, with its reference data [9]. But unfortunately, we were not able to isolate the reaction product 2,4-dimethylhexanoic acid. Thus, the

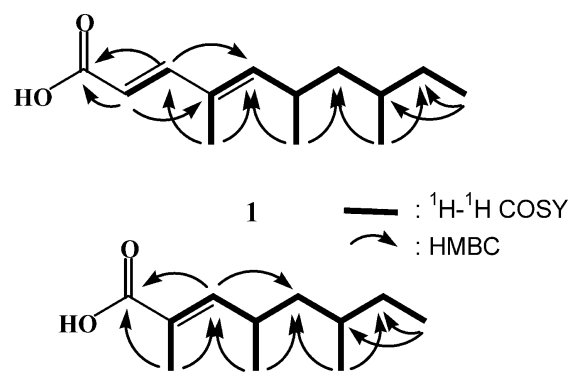

2

Fig. $3{ }^{1} \mathrm{H}^{-1} \mathrm{H} \quad \mathrm{COSY}$ and $\mathrm{HMBC}$ correlations of compounds $\mathbf{1}$ and $\mathbf{2}$.

stereochemistry of $\mathbf{1}$ still remains to be determined.

The structure of $\mathbf{2}$ was established by comparing its NMR data with those of $\mathbf{1}$. The ${ }^{1} \mathrm{H}$ - and ${ }^{13} \mathrm{C}$-NMR spectra of $\mathbf{2}$ were very similar to those of $\mathbf{1}$, except that the signals due to the two olefinic methines were missing. In the ${ }^{1} \mathrm{H}-{ }^{1} \mathrm{H}$ COSY spectrum, the methine proton at $\delta 2.64$ showed a cross peak to the methine proton at $\delta 6.66$ that was, in turn, correlated to the vinylic methyl protons at $\delta 1.87$ by allylic coupling. The structure of $\mathbf{2}$ was confirmed by the HMBC experiment, which showed the long-range correlations 
from $\mathrm{H}-8$ to $\mathrm{C}-6$ and $\mathrm{C}-7$, from $\mathrm{H}-9$ to $\mathrm{C}-1, \mathrm{C}-2$, and $\mathrm{C}-3$, from $\mathrm{H}-10$ to $\mathrm{C}-3, \mathrm{C}-4$, and $\mathrm{C}-5$, and from $\mathrm{H}-11$ to C-5, C-6, and C-7. Accordingly, the structure of 2 was established as 2,4,6-trimethyl-2-octenoic acid with undetermined stereochemistry at C-4 and C-6.

\section{Antimicrobial Activity and Cytotoxicity}

To date, many structurally-novel polypropionate metabolites have been isolated from marine bacteria and sponges, of which Mollusca was the most important source. Most members of this class have been reported to be against Gram-positive bacteria, yeast, and human cancer cell lines [10]. Interestingly, $\mathbf{1}$ and $\mathbf{2}$ exhibited potent antifungal activity (clear zone diameters of $16 \sim 20 \mathrm{~mm}$ ) against Pythium ultinum and Magnaporthe grisea, moderate activity (clear zone diameters of $11 \sim 15 \mathrm{~mm}$ ) against Aspergillus niger, Alternaria panax, and Fusarium oxysporium, and marginal activity against Phytophthora capsici, Alternaria mali, Alternaria porri, Botrytis cinerea, Rhizoctonia solani, Fulvia fulva, and Cylindrocarpon destructans, whereas they showed no activity against bacteria. In in vitro cytotoxicity of $\mathbf{1}$ and $\mathbf{2}$ estimated by MTT assay [8], these compounds exhibited no cytotoxic effect up to $200 \mu \mathrm{M}$ against the cancer cell lines, A549 (lung adenocarcinoma), HT-1080 (fibrosarcoma), and SW 620 (colorectal adenocarcinoma).

Acknowledgments This work was supported by a grant from the On-Site Cooperative Agriculture Research Project and a grant from the BioGreen 21 Program (20050401-034-645-196), RDA, Republic of Korea.

\section{References}

1. Jayasuriya H, Herath KB, Ondeyka JG, Polishook JD, Bills GF, Dombrowsky AW, Springer MS, Siciliano S, Malkowitz L, Sanchez M, Guan Z, Tiwari S, Stevenson DW, Borris RP, Singh S. Isolation and structure of antagonists of chemokine receptor (CCR5). J Nat Prod 67: 1036-1038 (2004)

2. Boonphong S, Kittakoop P, Isaka M, Pittayakhajonwut D, Tanticharoen M, Thebtaranonth Y. Multiplolides A and B, new antifungal 10-membered lactones from Xylaria multiplex. J Nat Prod 64: 965-967 (2001)

3. Smith CJ, Morin NR, Bills GF, Dombrowski AW, Salituro GM, Smith SK, Zhao A, MacNeil DJ. Novel sesquiterpenoids from the fermentation of Xylaria persicaria are selective ligands for the NPY Y5 receptor. J Org Chem 67: 5001-5004 (2002)

4. Lin $Y, W u X$, Feng S, Jiang G, Luo J, Zhou S, Vrijmoed LLP, Jones EBG, Krohn K, Steingrover K, Zsila F. Five unique compounds: xyloketals from mangrove fungus Xylaria sp. from the South China Sea coast. J Org Chem 66: 6252-6256 (2001)

5. Davis RA. Isolation and structure elucidation of the new fungal metabolite (-)-xylariamide A. J Nat Prod 68: 769-772 (2005).

6. Healy PC, Hocking A, Tran-Dinh N, Pitt JI, Shivas RG, Mitchell JK, Kotiw M, Davis RA. Xanthones from a microfungus of the genus Xylaria. Phytochemistry 65: 2373-2378 (2004)

7. Imazeki R, Hongo T. Colored Illustrations of Mushrooms of Japan. pp. 589-590, Hoikusha, Osaka (1989)

8. Mosmann T. Rapid colorimetric assay for cellular growth and survival: application to proliferation and cytotoxic assays. J Immunol Methods 65: 55-63 (1983)

9. White JD, Johnson A. Synthesis of the aliphatic depside (+)-bourgeanic acid. J Org Chem 59: 3347-3358 (1994)

10. Davies-Coleman MT, Garson M. Marine polypropionates. J Nat Prod Rep 15: 477-493 (1998) 